\title{
The Effect of Workplace Spirituality on Workplace Deviant Behavior and Employee Performance: The Role of Job Satisfaction
}

\author{
Rini Juni ASTUTI ${ }^{1}$, Tri MARYATI², Mugi HARSONO³
}

Received: September 10, 2020 Revised: November 02, 2020 Accepted: November 16, 2020

\begin{abstract}
This study aims to analyze the effect of workplace spirituality in reducing workplace deviant behavior through job satisfaction and its impact on employee performance. The objectives of this study are to explore and investigate (1) the effect of workplace spirituality on workplace deviant behavior; (2) the effect of workplace spirituality on job satisfaction; (3) the effect of workplace spirituality on employee performance; (4) the effect of job satisfaction on employee performance; (5) the effect of workplace deviant behavior on employee performance; and (6) the mediating role of job satisfaction in the relationship between workplace spirituality and workplace deviant behavior. This study was conducted with 143 permanent non-lecturer staff at Universitas Muhammadiyah Yogyakarta, Indonesia. The data analysis technique employed in this study was Structural Equation Modeling (SEM) based on Partial Least Square (PLS). The results of this study indicate that workplace spirituality affected workplace deviant behavior; workplace spirituality affected job satisfaction; job satisfaction affected employee performance; and workplace deviant behavior affected employee performance. Meanwhile, the findings further showed that workplace spirituality did not affect employee performance; job satisfaction did not affect workplace deviant behavior; and job satisfaction could not mediate the effect of workplace spirituality on workplace deviant behavior.
\end{abstract}

Keywords: Workplace Spirituality, Workplace Deviant Behavior, Job Satisfaction, Employee Performance

JEL Classification Code: M11, M12, M53, M54

\section{Introduction}

Workplace behavior supports human resources' management in higher education, which is increasingly competitive in a disruptive era, marked by the obligation to fulfill the abilities, skills, and competencies that must be possessed. Human resources, consisting of lecturers and non-lecturer staff, are identical with employees who strongly identify with their work organization, namely,

${ }^{1}$ First Author and Corresponding Author. [1] Business and Economic Faculty, Universitas Muhammadiyah Yogyakarta, Indonesia [2] PhD Student, Business and Economic Faculty, Universitas Sebelas Maret, Surakarta, Indonesia [Postal Address: Jl. Brawijaya, Tamantirto, Kec. Kasihan, Yogyakarta, 55183, Indonesia] Email: rinijuniastuti@umy.ac.id ${ }^{2}$ Business and Economic Faculty, Universitas Muhammadiyah Yogyakarta, Yogyakarta, Indonesia. Email: try_maryati@umy.ac.id ${ }^{3}$ Business and Economic Faculty, Universitas Sebelas Maret, Surakarta, Indonesia. Email: mugiharsono_fe@staff.uns.ac.id

(c) Copyright: The Author(s)

This is an Open Access article distributed under the terms of the Creative Commons Attribution Non-Commercial License (https://creativecommons.org/licenses/by-nc/4.0/) which permits unrestricted non-commercial use, distribution, and reproduction in any medium, provided the original work is properly cited. a more motivated attitude, more loyal to their organization, and better performance (Zhu, 2008). Organizational identification also substantially impacts the various areas of desired employee behaviors, attitudes, and cognitions (He \& Brown, 2013; Lee et al., 2015). These findings propel organizations into a "magic bullet" that seeks to increase employee engagement and individual performance even if, under certain circumstances, the magic bullet will incur some disadvantages (Galvin et al., 2015). The disadvantages can be in the form of low attendance rates, high employee turnover, and decreased organizational commitment, which is often referred to as workplace deviant behavior.

Workplace deviant behavior is a severe problem in companies (Appelbaum et al., 2006). Deviations are often recognized as reactions to individual stressors in organizations that frustrate them, such as financial, social, and working conditions (Lawrence \& Robinson, 2007). Deviant behaviors within the organization that often occur are unethical deviations and sometimes develop even within the organization. Unethical behavior is common and special in work organizations (Umphress \& Bingham, 2011). 
Today, a vital business trend to reduce workplace deviant behavior is employees' workplace spirituality (Shellenbarger, 2000). Although spirituality is a relatively new idea in the workplace, it is certainly not a new idea elsewhere in general on human experience (Ashmos \& Duchon, 2000). Workplace spirituality is not about religion but about employees who understand themselves as spiritual beings who need to nourish their souls in the office. Meanwhile, Lowery et al. (2014) suggested that spirituality appears to have an essential role in determining ethical beliefs about workplace behavior. Also, Ashmos and Duchon (2000) provided an accompanying definition of workplace spirituality as the most widely accepted and actually used conceptualization of the construct.

Further, workplace spirituality is a construction capable of reducing workplace deviant behavior so that employee performance will experience stability and even increase. This condition is especially true in higher education institutions, which are considered an education system with a critical mission to educate young people in a society. Workplace deviant behavior will cause harm as an event in the system, which consists of two kinds. First, such behavior reduces the system's efficiency and efficacy and hinders the organization from achieving its goals and mission (Ferris et al., 2009). Second, the occurrence of workplace deviant behavior at the university causes a culture of danger and a virus that will spread to the work environment.

The existing phenomenon at Universitas Muhammadiyah Yogyakarta, with AIPT accreditation "A", is the need to increase employee discipline to support the process of achieving performance, both individual and organizational performance, to compete nationally and internationally. UMY imposes an employee obligation, namely permanent non-lecturer staff, to take online performance assessments. During the last six years, it is known that there were still approximately $20 \%$ of employees who did not participate and did not pass the online performance appraisal or Employee Performance Unit (SKP). Besides, the educational personnel's discipline level, with the punctuality of attendance below $80 \%$, was approximately $21.6 \%$ of the total number of permanent educational personnel. It is a problem as the form of workplace deviant behavior, does not make the university work environment conducive, and can affect other employees' behaviors.

\section{Literature Review}

\subsection{Workplace Deviant Behavior}

When employees believe that their workplace is unfair, negative attitudes such as dissatisfaction, distrust, and stress emerge and develop, leading to workplace deviant behavior, affecting individuals and organizations. It is a form of employee considering workplace deviations, namely, as a consequence of unfair treatment or unfavorable social exchanges between employees and organizations as a form of social exchange theory's application (Homans, 1961). Workplace deviant behavior is defined as voluntary behavior, which significantly violates organizational norms, thereby threatening the organization or its members' welfare, or both (Robinson \& Bennett, 1995, 2000). It can also be explained that workplace deviant behavior toward individuals is referred to as interpersonal deviations, and that toward organization is referred to as organizational deviations (Bennett \& Robinson, 2000). Furthermore, workplace deviant behavior is organizational members' behavior intentionally carried out to violate rules or ignore values contrary to the organization's legitimate interests (Gruys \& Sackett, 2003). Workplace deviant behavior can also be described as an intentional or deliberate desire to harm the organization (Omar et al., 2011).

\subsection{Employee Performance}

Liao et al. (2012) define employee performance as the standard for progress, redundancy, reward, punishment, review, and salary changes. It is a requirement in fulfilling employee needs. On the other hand, employee performance is the primary building block of an organization, so that aspects that use the basis of high performance must be critically examined by the organization to succeed management and organization (Abbas \& Yaqoob, 2009). Employee performance symbolizes employees' broad beliefs about behavior and their contribution to organizational achievement (Ahmad and Khurram (2011). Donni (2016) affirms that employee performance is a real behavior displayed by everyone as a work. The achievements produced by employees are in accordance with their roles in the organization. The heuristic framework for individual performance is proposed as individual work results, consisting of four dimensions: task performance, contextual performance, adaptive performance, and counterproductive work behavior. These four types of behavior can be considered to capture various behaviors that shape individual job performance in almost all jobs (Koopmans et al., 2014).

\subsection{Workplace Spirituality}

Workplace spirituality seems to get researchers' attention when trying to define this construct (Van der Walt \& De Klerk, 2014). Spirituality has a broader meaning than religion (Ajala, 2013; Akbar et al., 2018). Laabs (1995) argued that religion should not be included when defining spirituality. Workplace spirituality is still not defined in concrete words and is still in the developing stage (Giacalone \& Jurkiewicz, 2003; Kolodinsky et al., 2007). Ashmos and Duchon (2000) 
elucidated that workplace spirituality is an understanding between individuals as spiritual beings whose souls need care at work with all the values within themselves, experiencing a sense of purpose and meaning in their work and a feeling of being connected to others and the community in which they work. Workplace spirituality aspects are briefly described as inner life (Mitroff \& Denton, 1999), a sense of togetherness (Milliman et al., 2003), meaningful work (Ashmos \& Duchon, 2000; Milliman et al., 2003), and work value (Ros et al., 1999).

\subsection{Job Satisfaction}

Organizational behavior scholars have conducted much research on job satisfaction. Job satisfaction is an employee's orientation toward their job (Malka \& Chatman, 2003). On the other hand, job satisfaction is the difference between the rewards expected and those received. The smaller the difference, the higher the satisfaction (Rai \& Sinha, 2002). Job satisfaction is usually treated as a collection of feelings or affective responses related to job situations or "just how people feel about various aspects of their work" (Spector, 1997: 2). Van der Walt and De Klerk (2014) asserted that job satisfaction theory is generally divided into the dispositional theory and needs fulfillment theory. The dispositional theory has its roots in 1913, where job satisfaction was considered a personality phenomenon (Judge et al., 2001; Saari \& Judge, 2004).

Meanwhile, needs fulfillment theory can be explained through Maslow's hierarchy needs (1954), stating that a person strives to grow to the self-actualization growth stage. Self-actualization is the point in a person's life at which he attains spiritual and emotional completeness. Besides, Minnesota's practice of measuring job satisfaction is one output of "The Job Adaptation Project" at the University of Minnesota. In his regard, Weiss et al. (1967) stated that the theory underlying Minnesota Job Satisfaction assumes that job suitability depends on the correspondence between individual skills and reinforcements in the work environment.

\section{Hypothesis Development}

\subsection{Workplace Spirituality and Workplace Deviant Behavior}

The conditions of organizational cynicism that lead to workplace deviant behavior have been carried out by researchers (Jiang et al., 2017; Li \& Chen, 2018), who suggested a possible link between workplace spirituality and workplace deviant behavior. Ahmad and Omar (2014) revealed that workplace spirituality could help employees measure workplace behavior because they can act as personal control. Thus, workplace spirituality could reduce workplace deviant behavior. Weitz et al. (2012) also found a negative relationship between workplace spirituality and bad organizational behavior. Moreover, the research results of Milliman et al. (2003) stated that the alignment of workplace spirituality includes, not only the alignment of values with the organization, but also the belief that the organization is ethical and has high integrity, so that workplace spirituality affects workplace deviant behavior, indicated by the condition of workplace spirituality that appears to be in direct conflict with workplace deviant behavior. The research results of Zhang (2018) found that workplace spirituality affected and was significant in deviant behavior. Furthermore, the research results of Septa (2018) and Siswanto (2018) stated that workplace spirituality influenced workplace deviant behavior. Also, qualitative research results (Sulaiman \& Bhatti, 2013) uncovered that strong workplace spirituality would help generate positive behavior and reduce deviant behavior in an organization. Thus,

H1: Workplace spirituality significantly affects workplace deviant behavior

\subsection{Workplace Spirituality and Job Satisfaction}

The work dimension of workplace spirituality implies that employees' jobs are perceived with joy and connect employees with the better (Duchon \& Plowman, 2005). The relationship between workplace spirituality and job satisfaction has not been studied much (Duffy, 2006), although there is increasing interest in studying this relationship. Previous studies conducted by Milliman et al. (2003) on part-time employees revealed that there was a significant positive relationship between dimensions of spirituality and job satisfaction. Later, other studies have shown the same results in organizations, where workplace spirituality impacted employees who experienced greater job satisfaction (Altaf \& Awan, 2011). Hence, employees whose spiritual needs are met tend to be more satisfied with their jobs. Thus, there is a positive influence between meaning in job satisfaction and job. The research results carried out by Zhang (2018), Hassan et al. (2016), Van der Walt and De Klerk (2014) discovered that workplace spirituality affected job satisfaction. The results of the same study were also conducted by Tasneem et al. (2017). Thus,

H2: Workplace spirituality significantly affects job satisfaction

\subsection{Workplace Spirituality and Employee Performance}

Research on workplace spirituality encouragement helps employees in the areas of creativity, process improvement, 
customer service, honesty and trust, personal fulfillment, and commitment, which ultimately lead to increased performance (Krishnakumar \& Neck, 2002). There were suggestions that the organization could encourage spiritual experiences that could improve organizational performance and profitability by empowering employees to perform more tasks. It makes it easier for employees to become more committed in the workplace and helps them make improvements and organizational progress. Therefore, employees and managers need to join in implementing workplace spirituality because it helps employees contribute more to the organization as a whole (Rabindra et al., 2015). Soha et al. (2016) stated that workplace spirituality could be used as an individual factor in influencing organizational performance. Further, Albuquerque et al. (2014) detailed this relationship through research that performance can be built with workplace spirituality, namely, a sense of community and a sense of purpose and meaningful work. Thus,

H3: Workplace spirituality significantly affects employee performance

\subsection{Job Satisfaction and Employee Performance}

Previous researchers have investigated the effect of job satisfaction on employee performance. Lin et al. (2014) argued that limited research had been conducted to investigate the relationship between job satisfaction and performance. Contradictory findings might be due to different individual factors, which contributed to job satisfaction. However, previous researchers have reported that job satisfaction is an essential element and positively affects job performance (Rodsutti and Swierczek, 2002). Research carried out by Djastuti et al. (2019), Inuwa (2016), Jalal et al. (2019), Khan (2012), Destari et al. (2018), Maryati et al. (2019), Nguyen (2020), Paais and Pattiruhu (2020), Pancasila et al. (2020), Putri et al. (2019) confirmed that job satisfaction influenced employee performance. Thus,

H4: Job satisfaction significantly affects employee performance.

\subsection{Workplace Deviant Behavior and Employee Performance}

Workplace deviant behavior is the scope of all forms of behavior deliberately carried out by organization members, contrary to organizational goals (Piskin, 2014). Besides, deviant behavior is any deliberate individual activity, which can hinder the performance of oneself, others, or the organization (Chand \& Chand, 2014). In other words, workplace deviant behavior can harm oneself, others, and organizational resources. Uncontrolled workplace deviant behavior will cause employee performance to degrade.
Several research results exposed that workplace deviant behavior impacted individual/employee performance (Muafi, 2011). The same research results were also discovered by Yupono (2018). Thus,

H5: Workplace deviant behavior significantly affects employee performance

\subsection{Job Satisfaction and Workplace Deviant Behavior}

Judge et al. (2006) states that job satisfaction indicates that the power of employee satisfaction affects efficient output work conduct, such as increased extra role, imaginative, productive activities, and job performance, while decreasing workplace deviant behavior withdrawal, turnover and immoral activities in the workplace. The research result by Malhotra et al. (2017) affirmed that job satisfaction affects to counterproductive work behavior. The same research results were also discovered by Appelbaum et al. (2006) and Mahyarni (2019). Thus,

H6: Job Satisfaction significantly affects workplace deviant behavior

\subsection{Job Satisfaction Mediates the Influence of Workplace Spirituality on Workplace Deviant Behavior}

In the relationship between job satisfaction and the dimensions of workplace spirituality, spirituality will be mediated by influential job satisfaction. Spirituality is a universal phenomenon, where organizations acknowledge that people who work in their companies have an inner life, which grows because of the meaningful work for their lives and continuous employee job satisfaction. The research results by Crede et al. (2007) affirmed that job satisfaction plays a mediating role in the influence of the dimensions of workplace spirituality on workplace deviant behavior. The results are also supported by research conducted by Zhang (2018). Thus,

H7: Job satisfaction mediates the influence of workplace spirituality on workplace deviant behavior.

\section{Research Methods}

Research subjects/objects were permanent non-lecturer staff of Universitas Muhammadiyah Yogyakarta (UMY). The sample was permanent non-lecturer staff of Universitas Muhammadiyah Yogyakarta, with the sampling method used was purposive sampling. This study's respondents were permanent non-lecturer staff meeting the criterion of working at least five years. 


\subsection{Data Collection}

The type of data employed was primary data, where the primary data collection method was done by online (Google form) and offline (questionnaires distributed to employees). The questionnaire consisted of demographic questions and structured research questions. The number of questionnaires filled was 165 questionnaires by permanent non-lecturer staff who fit the criteria. Meanwhile, 143 questionnaires could be analyzed; the rest of the questionnaires were incomplete or flawed.

\subsection{Measurement}

Workplace deviant behavior (Y1) was measured by the dimension of workplace deviant behavior proposed by Robinson and Bennet (2000). Employee performance (Y2) was calculated by the individual performance dimensions, with five items developed by Koopmans et al. (2014). Workplace spirituality (X1) was determined by workplace spirituality dimensions using 14 items by Ashmos and Duchon (2000). Workplace deviant behavior (X2) was evaluated by the dimension of workplace deviant behavior, with eight items developed by Robinson and Bennet (2000). Job satisfaction (X3) was gauged by the dimensions of job satisfaction, the Minnesota Satisfaction Questionnaire of 20 items by Weiss et al. (1967). The measurement scale utilized a 5-point Likert scale ( $1=$ strongly disagree, $2=$ disagree, 3 $=$ neutral, $4=$ agree and $5=$ strongly agree).

This study's analytical tool utilized a structural equation model based on Partial Least Square (PLS). Smart PLS 3.0 software was used to help analyze the relationship between variables. PLS was employed for hypothesis testing, which was done partially (t-test), and the mediation test used the Sobel test. Meanwhile, descriptive analysis was employed to interpret the respondent's data.

\section{Results}

Based on the results of the distributed questionnaire, the respondents' demographic conditions, including gender, years of service, and age of the UMY non-lecturer staff show that most respondents' were female (78\%), most had a work

Table 1: Reliability Test Results

\begin{tabular}{|l|c|c|}
\hline Variable & $\begin{array}{c}\text { Cronbach's } \\
\text { alpha }\end{array}$ & Explanation \\
\hline Workplace Spirituality (WPS) & 0.868 & Reliable \\
\hline $\begin{array}{l}\text { Workplace Deviant Behavior } \\
\text { (DB) }\end{array}$ & 0.803 & Reliable \\
\hline Job Satisfaction (KK) & 0.892 & Reliable \\
\hline Employee Performance (KP) & 0.805 & Reliable \\
\hline
\end{tabular}

period of 15 years and over (55\%), and most respondents' age was between 30 and 40 (45\%).

Based on the results of the data processing, the mean value of workplace spirituality was 4.32 . It can be said that UMY non-lecturer staff's workplace spirituality was good, with an average standard deviation of 0.40 . Meanwhile, the mean value of workplace deviant behavior of UMY nonlecturer staff was 4.24 , and the average standard deviation was 0.44 . It can be said that there were not many workplace deviant behaviors among UMY non-lecturer staff. Besides, the mean value of job satisfaction was 4.00, and the average standard deviation was 0.41 . It can be said that the UMY non-lecturer staff's job satisfaction was good. Furthermore, the mean value of employee performance was 4.34 , with an average standard deviation of 0.39 . Thus, it can be said that UMY non-lecturer staff's performance was good.

From the descriptive analysis results, the standard deviation value was below the mean value, so it can be said that the data on workplace spirituality, workplace deviant behavior, job satisfaction, and employee performance were homogeneous. Also, the standard deviation value was below the mean value, so that it can be said that all data were homogeneous.

The reliability test used Cronbach's alpha. The data are reliable if Cronbach's alpha is above 0.7 (Nunally, 1978). From the results of data processing in Table 1, it can be seen that Cronbach's alpha value for each variable was reliable.

Inner model testing in Table 2 was performed by looking at the R-Square (R2) value in the dependent construct. The latent variable of workplace deviant behavior could be explained by the latent variable of workplace spirituality, which was $51.2 \%$. Meanwhile, the remaining $48.8 \%$ was explained by other variables not examined in this research model. Besides, the R2 value of the latent variable job satisfaction was 30.78. It indicated that the latent variable of job satisfaction could be explained by the latent variable of workplace spirituality, while $69.22 \%$ was explained by other variables outside this study. Moreover, the R2 value of the latent variable employee performance was $54.8 \%$. It signified that the latent variable of employee performance could be explained by variables of spirituality in the workplace and job satisfaction. Meanwhile, 45.2\% was explained by other variables outside the study.

Table 2: R-Square Results

\begin{tabular}{|l|c|}
\hline & R Square \\
\hline Workplace Spirituality & \\
\hline Workplace Deviant Behavior & 0,512039 \\
\hline Job Satisfaction & 0,307814 \\
\hline Employee Performance & 0,547941 \\
\hline
\end{tabular}


The next test was to see the significance of the effect between the independent (exogenous) constructs on the dependent (endogenous) construct and to answer what has been hypothesized. On testing with a significance level of $5 \%$, if the value of t-statistics was $>1.96$, the null hypothesis (H0) was rejected.

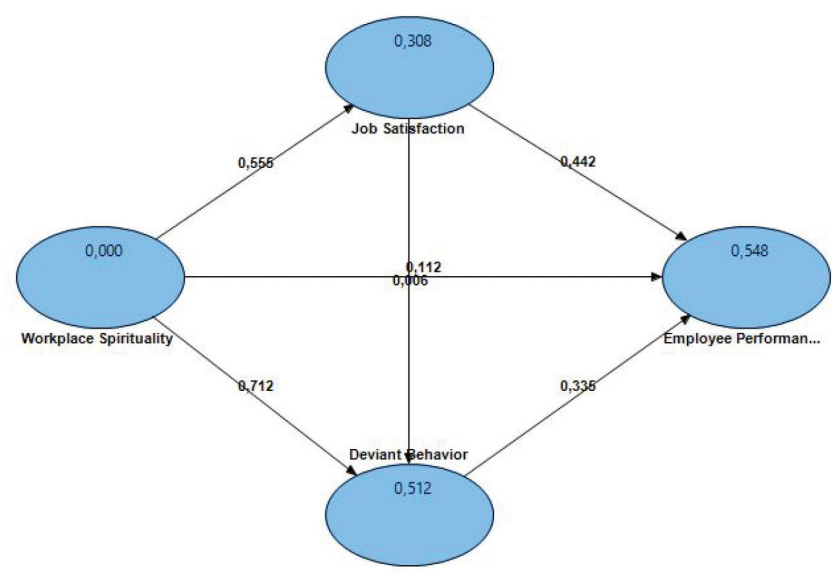

Figure 1: Research Model

\section{Discussion}

\subsection{Workplace Spirituality and Workplace Deviant Behavior}

Based on the t-test using the Partial Least Square (PLS) in Figure 1 and Table 3, it is known that workplace spirituality affected and was significant in workplace deviant behavior with a coefficient value of 0.712 and significant with an at-count value of 10.961349 more than the t-table of 1.96. Hypothesis 1 was supported, stating that workplace spirituality had a significant effect on workplace deviant behavior. It is in line with the research results of Zhang (2018), Septa, (2018), and Siswanto (2018), which asserted that workplace spirituality influenced and was significant on deviant behavior. The same result was also revealed by Sulaiman and Bhatti (2013). Non-lecturer staff can implement workplace spirituality, which is the meaning of work in the form of happiness in the work, both for themself and others, for the results of their work, the desire to work every day; there is a sense of togetherness with the environment and alignment of value in the form of spiritual values in every educational workforce, so that workplace deviant behavior can be reduced in getting the job done.

Table 3: Path Coefficients (Mean, STDEV, T-Values)

\begin{tabular}{|l|l|c|c|c|c|c|c|}
\hline \multicolumn{2}{|l|}{ Hypotheses } & $\begin{array}{c}\text { Original } \\
\text { Sample }\end{array}$ & $\begin{array}{c}\text { Sample } \\
\text { Mean }\end{array}$ & $\begin{array}{c}\text { Standard } \\
\text { Deviation }\end{array}$ & $\begin{array}{c}\text { Standard } \\
\text { Error }\end{array}$ & T Statistics & Results \\
\hline H1 & $\begin{array}{l}\text { Workplace Spirituality } \\
->\text { Workplace Deviant } \\
\text { Behavior }\end{array}$ & 0,712497 & 0,719291 & 0,065001 & 0,065001 & 10,961349 & Accepted \\
\hline H2 & $\begin{array}{l}\text { Workplace Spirituality -> } \\
\text { Job Satisfaction }\end{array}$ & 0,554810 & 0,580331 & 0,085074 & 0,085074 & 6,521498 & Accepted \\
\hline H3 & $\begin{array}{l}\text { Workplace Spirituality -> } \\
\text { Employee Performance }\end{array}$ & 0,112316 & 0,119639 & 0,133192 & 0,133192 & 0,843264 & Rejected \\
\hline H4 & $\begin{array}{l}\text { Job Satisfaction -> } \\
\text { Employee Performance }\end{array}$ & 0,442106 & 0,430106 & 0,085343 & 0,085343 & 5,180313 & Accepted \\
\hline H5 & $\begin{array}{l}\text { Workplace Deviant } \\
\text { Behavior -> Employee } \\
\text { Performance }\end{array}$ & 0,334977 & 0,342730 & 0,100990 & 0,100990 & 3,316936 & Accepted \\
\hline H6 & $\begin{array}{l}\text { Job Satisfaction -> } \\
\text { Workplace Deviant } \\
\text { Behavior }\end{array}$ & 0,005511 & 0,006868 & 0,096532 & 0,096532 & 0,057092 & Rejected \\
\hline
\end{tabular}




\subsection{Workplace Spirituality and Job Satisfaction}

Based on the t-test using the Partial Least Square (PLS) in Figure 1 and Table 3, it is known that workplace spirituality significantly impacted job satisfaction and was significant, with a coefficient value of 0.558 and at-count value of 6.521498 , which was more than the t-table of 1.96 . Hypothesis 2, stating that workplace spirituality significantly affected job satisfaction, was accepted. It is in line with the research of Zhang (2018), Hassan et al. (2016), and Van der Walt and De Klerk (2014), which showed that workplace spirituality influenced job satisfaction. The results of the same study were also produced by Tasneem et al. (2017). This study illustrates that, when non-lecturer staff's workplace spirituality (meaning work, sense of community, and alignment of value) is good, then job satisfaction is achieved.

\subsection{Workplace Spirituality and Employee Performance}

Based on the t-test using the Partial Least Square (PLS) in Figure 1 and Table 3, it is known that workplace spirituality did not affect employee performance with a coefficient value of 0.112 and t-count value of 0.843264 smaller than the t-table of 1.96. Hypothesis 3 was rejected, which stated that workplace spirituality had a significant effect on employee performance. This study's results are not consistent with the research by Soha et al. (2016) and Albuquerque et al. (2014). However, this study's results are coherent with the findings of Pratama (2014) and Umam et al. (2017), where workplace spirituality did not affect employee performance. The relationship between workplace spirituality and employee performance still leaves a research gap that can still be developed into a research problem in further studies. Workplace spirituality (meaning work, sense of community and alignment of value) of non-lecturer staff does not affect employee performance. This is because the performance of the non-lecturer staff workforce is already well underway with the culture of institutional organizations that obliged staff to participate, and self-awareness to provide contingency results to institutions to continuously improve their performance through existing online performance systems.

\subsection{Job Satisfaction and Employee Performance}

Based on the t-test using the Partial Least Square (PLS) in Figure 1 and Table 3, job satisfaction impacted employee performance and was significant, with a coefficient value of 0.442 and at-count value of 5.180313, which was higher than the t-table of 1.96. Hypothesis 4, which stated that job satisfaction significantly affected employee performance, was supported. This study's results are in line with research conducted by Rodsutti and Swierczek (2002), Inuwa (2016), Khan (2012), and Destari et al. (2018). Based on the theory of Job satisfaction two factors from Herzberg (Lindsay et al., 1967), in the form of motivation and hygiene, have been felt by non-lecturer staff improving the performance of the employees or the results of their work. Besides, job satisfaction is seen by the achievement of obtaining performance benefits based on annual performance.

\subsection{Workplace Deviant Behavior and Employee Performance}

Based on the t-test using the Partial Least Square (PLS) in Figure 1 and Table 3, it is known that workplace deviant behavior had an effect on employee performance and was significant, with a coefficient value of 0.335 and at-count value of 3.316936, higher than the t-table of 1.96. Hypothesis 5 was accepted, which states that workplace deviant behavior significantly affected employee performance. It supports the research of Muafi (2011) and Yupono (2018). Workplace deviant behavior in the form of indiscipline, non-compliance with rules and leadership, and misuse of low facilities, make the performance of non-lecturer staff or the work of the non-lecturer staff increase. This is also due to good selfawareness of his role as a non-lecturer staff and because of the understanding of the work, the sense of togetherness, and alignment of good value.

\subsection{Job Satisfaction and Workplace Deviant Behavior}

Based on the t-test using the Partial Least Square (PLS) in Figure 1 and Table 3, it is known that had an effect Job Satisfaction on workplace deviant behavior and was significant, with a coefficient value of 0,005 and atcount value of 0,057092 , lower than the t-table of 1.96 . Hypothesis 6 was rejected, which stated that job satisfaction had a significant effect on workplace deviant behavior. This study's results are not consistent with the research done by Malhotra et.al (2017), Appelbaum et al. (2006), Roznowski and Hulin, in Yusof (2011), and Mahyarni (2019). However, this study's results are coherent with the findings of Bowling (2010) and Nakasi (2019) where job satisfaction did not affect counterproductive behavior. Bowling (2010) state that was evidenced by working conditions or experiences for example favorable job attitudes. Every non-lecturer staff already feels attachment and diss edited activities according to the culture of the organization that exists in the workplace, so that when there are various workplace deviant behaviors, they try not to violate. Job satisfaction has been perceived to have no impact on the decrease in deviant behavior. 


\subsection{Job Satisfaction Mediates the Influence of Workplace Spirituality on Workplace Deviant Behavior}

Based on the calculation results of the Sobel test (https:// www.danielsoper.com), the Sobel test statistic value was $0.05707851<1.96$, with a significance level of $5 \%$. It proved that job satisfaction could not mediate the influence of workplace spirituality on workplace deviant behavior. Therefore, Hypothesis 7, which stated that job satisfaction mediated the effect of workplace spirituality on workplace deviant behavior, was rejected. These results do not support the study by Crede et al. (2007) and Zhang (2018). It happened in the condition of the UMY non-lecturer staff in their self-meaning, sense of togetherness, and organizational values that had fused into themselves, so that deviant behavior due to job dissatisfaction in the workplace did not occur. It was also because they have already had awareness, which was an obligation and commitment not to abuse the organization's activities and resources without going through the job satisfaction they felt.

\section{Conclusion}

This study results indicate that some factors had effects and others had none. Those that had effects included workplace spirituality, which affected workplace deviant behavior; workplace spirituality, which influenced job satisfaction; job satisfaction, which impacted employee performance; and workplace deviant behavior, which affected employee performance. Meanwhile, the research results showed that workplace spirituality did not affect employee performance, job satisfaction did not influence workplace deviant behavior and job satisfaction could not mediate the influence of workplace spirituality on workplace deviant behavior.

Research results that did not show effects include workplace spirituality, which did not affect employee performance, and job satisfaction, which could not mediate the effect of workplace spirituality on workplace deviant behavior. There is still a research gap that should be investigated in subsequent research by proposing other variables as mediation and moderation.

\section{References}

Abbas, Q., \& Yaqoob, S. (2009). Effect of leadership development on employee performance in Pakistan. Pakistan Economic and Social Review, 47(2), 269-292.

Ahmad, S., \& Shahzad, K. (2011). HRM and employee performance: A case of university teachers of Azad Jammu and Kashmir (AJK) in Pakistan. African Journal of Business Management, 5(13), 5249-5253.

Ahmad, A., Omar, Z., 2014. Reducing deviant behavior through workplace spirituality and job satisfaction. Asian Social Science, 10(19), 107-112.
Ajala, E. M. (2013). The Impact of Workplace Spirituality and Employees' Wellbeing at the Industrial Sector: The Nigerian Experience. The African Symposium. 13(2), 3-13.

Akbar, A. B., Udin, Wahyudi, S., \& Djastuti, I. (2018). Spiritual Leadership and Employee Performance: Mediating Role of Organizational Commitment in Indonesian Public University. Journal of Engineering and Applied Sciences, 13(12), 43444352.

Albuquerque, I. F., Cunha, R. C., Martins, L. D., \& Britosa. A. (2014). Journal of Organizational Change Management, 27(1), 59-82.

Altaf, A., \& Awan, M. A. (2011). Moderating effect of workplace spirituality on the relationship of job overload \& job satisfaction. Journal of Business Ethics, 104(1), 93-99. http:// dx.doi.org/10.1007/s10551-011-0891-0

Appelbaum, S.H., Shapiro, B.T., \& Molson, J. (2006). Diagnosis and remedies for deviant workplace behaviors. Journal of American Academy of Business, 9(2), 14-20.

Ashmos, D., \& Duchon, D. (2000). Spirituality at work. Journal of Management Inquiry, 9(2), 134-145. http://dx.doi. org/10.1177/105649260092008

Bowling, N. A., Eschleman, K. J., \& Wang, Q. (2010). A meta-analytic examination of the relationship between job satisfaction and subjective well-being. Journal of Occupational and Organizational Psychology, 83, 915-934.

Chand, P., \& Chand, P. K. (2014). Emotional Competencies towards Counterproductive Work Behaviour in Banking Sector. International Journal of Science and Research, 3(12), 459-467.

Crede, M., Chernyshenko, O. S., Stark, S., Dalal, R. S., \& Bashshur, M. R. (2007). Job satisfaction as mediator: An assessment of job satisfaction's position within the nomological network. Journal of Occupational and Organizational Psychology, 80(3), 515-538.

Destari, Y., Lumbanraja, P., \& Absah, Y. (2018). The Influence of Work Satisfaction on Employees Performance with Organizational Commitment as Intervening Variable at the Mining and Energy Agency of North Sumatera. International Journal of Research \& Review, 5(12), 355-364.

Djastuti, I., Rahardjo, S., Irviana, L., \& Udin, U. (2019). Fun at work and employee performance: the roles of job satisfaction and organizational commitment in manufacturing companies. WSEAS Transactions on Business and Economics, 16, 153-162.

Duchon, D., \& Plowman, D. (2005). Nurturing the spirit at work: Impact on work unit performance. The Leadership Quarterly, 16(5), 807-833. https://doi.org/10.1016/j.leaqua. 2005.07.008.

Duffy, R. D. (2006). Spirituality, religion, and career development: Current status and future directions. The Career Development Quarterly, 55(1), 52-63. http://dx.doi. org/10.1002/j.2161-0045.2006.tb00004.x

Ferris, D. L., Brown, D. J., \& Heller, D. (2009). Organizational supports and organizational deviance: The mediating role of organization-based self-esteem. Organizational Behavior 
and Human Decision Processes, 108(2), 279-286. https://doi. org/10.1016/j.obhdp.2008.09.001

Galvin, B. M., Lange, D., \& Ashforth, B.E. (2015). Narcissistic Organizational Identification: Seeing Oneself as Central to the Organization's Identity. The Academy of Management Review, 40(2), 163-181.

Giacalone, R. A., \& Jurkiewicz, C. L. (2003). Toward a science of workplace spirituality. In: Giacaloneand R. A., \&Jurkiewicz, C. L. (eds.), Handbook of Workplace Spirituality and Organizational Performance. Armonk, NY: M.E. Sharpe.

Gruys, M.L., \& Sackett, P.R.(2003). Investigating the dimensionality of counterproductive work behavior. International Journal of Selection and Assessment, 11(1), 30-42. https://doi. org/10.1111/1468-2389.00224.

Hassan, M., Bin Nadeem, A., \& Akhter, A. (2016). Impact of workplace spirituality on job satisfaction: Mediating effect of trust. Cogent Business \& Management, 3(1). https://doi.org/10. 1080/23311975.2016.1189808.

He, H., \& Brown, A. (2013). Organizational Identity and Organizational Identification A Review of the Literature and Suggestions for Future Research. Group \& Organization Management, 38(1), 3-35.

Homans, G. C. (1961). Social behavior: Its elementary forms. San Diego, CA: Harcourt, Brace.

Inuwa, M. (2016). Job Satisfaction and Employee Performance: An Empirical Approach. The Millennium University Journal, 1(1), 90-103.

Jalal, R. N. U. D., Zeb, N., \& Fayyaz, U. E. R. (2019). The Effect of Personality Traits on Employee Job Satisfaction with Moderating Role of Islamic Work Ethics. Journal of Asian Finance, Economics and Business, 6(2), 161-171. https://doi. org/10.13106/jafeb.2019.vol6.no2.161

Jiang, H., Chen, Y., Sun, P., Yang, J. (2017). The relationship between authoritarian leadership and employees' deviant workplace behaviors: the mediating effects of psychological contract violation and organizational cynicism. Frontiers in Psychology, 8, 732.

Judge, T.A., Scott, B.A. and Ilies, R. (2006). Hostility, job attitudes, and workplace deviance: test of a multilevel model. Journal of Applied Psychology, 91(1), 126-138.

Khan, A. H., Nawaz, M. M., Aleem, M., \& Hamed, W. (2012). Impact of job satisfaction on employee performance: An empirical study of autonomous Medical Institutions of Pakistan. African Journal of Business Management, 6(7), 2697-2705,

Kolodinsky, R.W., Giacalone, R. A. Juckiewicz, C. L. (2007). Work values and outcomes: Exploring personal, organizational and interactive workplace spirituality. Journal of Business Ethics, $81,465-480$.

Koopmans, L., Bernaards, C., Hildebrandt, V., van Buuren, S., van der Beek, A. J., \& De Vet, H. (2014). Development of an Individual Work Performance Questionnaire. International Journal of Productivity and Performance Management, 62(1), 6-28.
Krishnakumar, S., \& Neck, C. P. (2002). The "What", "Why", and "How" of spirituality in the workplace. Journal of Managerial Psychology, 17(3), 153-164.

Laabs, J. J. (1995). Balancing spirituality and work. Personnel Journal, 74(9), 60-62.

Lawrence, T. B., \& Robinson, S. L. (2007). Ain't Misbehavin: Workplace Deviance as Organizational Resistance. Journal of Management, 6 .

Lee, Y. K., Kim, S. H., Seo, M. K., \& Hight, S. K. (2015). Market orientation and business performance: Evidence from franchising industry. International Journal of Hospitality Management, 44, 28-37. https://doi.org/10.1016/j. ijhm.2014.09.008

Liao, C. W., Lu, C. Y., Huang, C. K., \& Chiang, T. L. (2012). Work values, work attitude and job performance of green energy industry employees in Taiwan. African Journal of Business Management, 6(15), 5299-5318.

Li, S., \& Chen, Y. (2018). The relationship between psychological contract breach and employees' counter productive work behaviors: the mediating effect of organizational cynicism and work alienation. Frontiers in Psychology, 9, 1273. https://doi. org/10.3389/fpsyg.2018.01273.

Lin, S., Lamond, D., Yang, C. L., \& Hwang, M. (2014). Personality traits and simultaneous reciprocal influences between job performance and job satisfaction. Chinese Management Studies, 8(1), 6-26. https://doi.org/10.1108/CMS-09-2011-0079

Lindsay, C. A., Marks, E., \& Gorlow, L. (1967). The Herzberg Theory: A critique and reformulation. Journal of Applied Psychology, 51(4), 330-339. https://doi.org/10.1037/h0024868

Mahyarni. (2019). The influence of spiritual leadership and its impacts on the reduction of workplace deviant behavior. International Journal of Public Leadership, 15(3), 170-188. DOI 10.1108/IJPL-01-2019-0003

Malhotra, M., \& Kathuria, K. (2017). Relationship between Spiritual Intelligence, Job Satisfaction and Counterproductive work behaviour among employees of multinational companies in India. Journal of Psychosocial Research, 12(2), 315-323.

Malka, A., \& Chatman, J. A. (2003). Intrinsic and extrinsic work orientation as moderators of effects of annual income on subjective well-being: A longitudinal study. Personality and Social Psychology Bulletin, 29(6), 737-746.

Maryati, T., Astuti, R. J., \& Udin, U. (2019). The Effect of Spiritual Leadership and Organizational Culture on Employee Performance: The Mediating Role of Job Satisfaction. International Journal of Innovation, Creativity and Change, 9(3), 130-143.

Milliman, J., Czaplewski, A. J., \& Ferguson, J. (2003). Workplace spirituality and employee work attitudes: An exploratory empirical assessment. Journal of Organizational Change Management, 16(4), 426-447. http://dx.doi. org/10.1108/09534810310484172

Mitroff, I. I. \& Denton, E. A. (1999a). A spiritual audit of corporate America; A hard look at spirituality, religion, and values in the workplace. San Francisco, CA: Jossey-Bass. 
Muafi, U. (2011). Causes and consequence deviant workplace behaviour. International Journal of Innovation, Management and Technology, 2(2), 123-126.

Nakasi, M. (2019). Employee Emotionality, Job Satisfaction and Counterproductive Work Behavior among Employees of Uganda Red Cross Society Lubaga. Dissertation, School of Psychology, Makerere University.

Nguyen, T. H. (2020). Impact of Leader-Member Relationship Quality on Job Satisfaction, Innovation and Operational Performance: A Case in Vietnam. Journal of Asian Finance, Economics and Business, 7(6), 449-456. https://doi. org/10.13106/jafeb.2020.vol7.no6.449

Nunnally, J. C. (1978). Psychometric theory ( $2^{\text {nd }}$ ed.). New York, NY: McGraw-Hill.

Omar, F., Halim F. W., Zainah, A. Z, Farhadi, H., Nasir, R., Khairudin, R. (2011) Stress and Job Satisfaction as Antecedents of Workplace Deviant Behavior. World Applied Sciences Journal, 46-53.

Paais, M., \& Pattiruhu, J. R. (2020). Effect of Motivation, Leadership, and Organizational Culture on Satisfaction and Employee Performance. Journal of Asian Finance, Economics and Business, 7(8), 577-588. https://doi.org/10.13106/ jafeb.2020.vol7.no8.577

Pancasila, I., Haryono, S., \& Sulistyo, B. A. (2020). Effects of Work Motivation and Leadership toward Work Satisfaction and Employee Performance: Evidence from Indonesia. Journal of Asian Finance, Economics and Business, 7(6), 387-397. https:// doi.org/10.13106/jafeb.2020.vol7.no6.387

Putri, E. R., Udin, U., \& Djastuti, I. (2019). Structural Empowerment and Service-Oriented Organizational Citizenship Behavior: The Mediating Roles of Innovativeness and Job Satisfaction. Quality-Access to Success, 20(170), 112-117.

Rabindra, K. P., Panigrahy, N. P., \& Jena, L. K. (2015). Workplace Spirituality and Employee Performance: Mediating Role of Organisation Citizenship Behaviour. Journal of Contemporary Psychological Research, 2(1).

Rai, S., \& Sinha, A. K. (2002). Job Delight: Beyond job satisfaction. Indian Journal of Industrial Relations, 37(4), 554-571.

Robinson, S., \& Bennett, R. (1995). A typology of deviant workplace behaviors: A multi-dimensional scaling study. Academy of Management Journal, 38, 555-572.

Robinson, S. \& Bennett, R. (2000). Development of a measure of workplace deviance. Journal of Applied Psychology, 85, 349360.

Rodsutti, M. C., \& Swierczek, F. (2002). Leadership and organizational effectiveness in multinational enterprises in Southeast Asia. Leadership \& Organization Development Journal, 23(5), 250-259. https://doi. org/10.1108/01437730210435965

Ros, M., Schwartz, S. H., \& Surkiss, S. (1999). Basic individual values, work values, and the meaning of work. Applied Psychology: An International Review, 48, 49-71.

Saari, L. M., \& Judge, T. A. (2004). Employee attitudes and job satisfaction. Human Resource Management, 43(4), 395-407.
Septa, A. M. (2018). The Influence of Spirituality on Deviant Behavior in the Workplace with Job Satisfaction as a Mediator Among Teachers at State High School Banda Aceh City. Management Economics Student Scientific Journal, 3(3), 129142. [Indonesian]

Shellenbarger, S. (2000). More relaxed boomers, fewer workplace frills and other job trends. Wall Street Journal, 3(1), 24-30.

Siswanto. (2018). The Implementation of Islamic Spirituality and Islamic Social Responsibility on Islamic Banking Employees, It's Implication Towards Workplace Deviance. Management and Economic Journal, 2(1), 1-16.

Soha, H. M., Osman, A., Salahuddin, S. M., Abdullah, S., \& Ramlee, N. F. (2016). The Relationship of Work Influence, Sense of Community, and Individual Spirituality towards Organizational Performance. Procedia Economics and Finance, 35, 591-596.

Sulaiman, M., \& Bhatti, O. K. (2013). Workplace deviance and spirituality in Muslim organizations. Asian Social Science, 9(10), 237-246.

Tasneem, F. A., Summaya, A. N., Kausar, C., \& Khawaja, F. (2017). Workplace spirituality and job satisfaction: Moderating role of intrinsic and extrinsic values. A Research Journal of Commerce, Economics, and Social Sciences, 11(1), 58-66

Umam, M., Khairul, R., \& Fahma, A. Z. (2017). Relationship of Employee Workplace Spirituality and Employee Performance: a Mediating Perspective of Islamic Work Ethics. Jurnal Bisnis dan Manajemen Islam, 5(1). http://dx.doi.org/10.21043/bisnis.v5i1

Umphress, E. E., \& Bingham, J. B. (2011). When employees do bad things for good reasons: Examining unethical proorganizational behaviors. Organization Science, 22(3), 621640. https://doi.org/10.1287/orsc.1100.0559.

Van Der Walt, F., \& De Klerk, J. (2014). Workplace Spirituality and Job Satisfaction. International Review of Psychiatry, 26(3), 379-389. https://doi.org/10.3109/09540261.2014.908826.

Weiss, D. J., Dawis, R. V. England, G. W., \& Lofquist, L. H. (1967). Manual for the Minnesota Satisfaction Questionnaire. Vol. 22, Minnesota Studies in Vocational Rehabilitation. Minneapolis: University of Minnesota, Industrial Relations Center.

Weitz, E., Vardi, Y., Setter, O. (2012). Spirituality and organizational misbehaviour. Journal of Management, Spirituality and Religion, 9(3), 255-281. https://doi. org/10.1080/14766086.2012. 730782 .

Yupono, B. (2018). The Effect of Counterproductive Work Behavior (CWB) And Organizational Citizenship Behavior (OCB) on Employee Performance with Employee Engagement As Intervening Variable. IOSR Journal of Business and Management, 20(2).

Yuri, D., Lumbanraja, P., \& Absah, Y. (2018). The Influence of Work Satisfaction on Employees Performance with Organizational Commitment as Intervening Variable at the Mining and Energy Agency of North Sumatera. International Journal of Research and Review.

Zhang, S. (2018). Workplace Spirituality and Unethical Proorganizational Behavior: The Mediating Effect of Job Satisfaction. Journal of Business Ethics. https://doi. org/10.1007/s10551-018-3966-3. 